\section{E A Institute of \\ YK Business Administration \\ 光 \\ Karachi \\ Leadership and Ideas for Tomorrow}

\section{Business Review}

Volume 2 Issue 2 July-December 2007

7-1-2007

\title{
Branding Pakistan for the future
}

Umair Naeem

Institute of Business Administration, Karachi, Pakistan

Follow this and additional works at: https://ir.iba.edu.pk/businessreview

Part of the Marketing Commons

c) (i)

This work is licensed under a Creative Commons Attribution 4.0 International License.

\section{Recommended Citation}

Naeem, U. (2007). Branding Pakistan for the future. Business Review, 2(2), 134-149. Retrieved from https://doi.org/10.54784/1990-6587.1394

This article is brought to you by iRepository for open access under the Creative Commons Attribution 4.0 License and is available at https://ir.iba.edu.pk/businessreview/vol2/iss2/9. For more information, please contact irepository@iba.edu.pk. 


\title{
DISCUSSION
}

\section{Branding Pakistan For The Future}

\author{
Umair Naeem \\ Institute of Business Administration, Karachi, Pakistan
}

\section{INTRODUCTION}

\subsection{BACKGROUND AND CONCEPTS}

$\mathrm{B}$ randing products has been a concept that has been there and thereabout since the ages, and internationally it has gained prominence as a means for building a product or service's identity and personality. Brands such as Nike and Apple stand as testament to the massive influence that Branding a product successfully can have on its future and popularity. Both the said Brands evoke feelings in almost all consumers' mind that other products can only envy.

Branding hence looks to provide a product or a service with an identity, which can be called its own, and exist for the infinite future. Branding, thus, turns a generic product into an entity with a name and with attributes, which can evoke associations and feelings, and which has a distinct personality.

It would be myopic to look at Branding purely as a means of selling products and services; rather, as the many examples in this paper will testify to, it can be a great means of packaging and marketing a country or a city. We will look into Branding in more detail in the next sections.

\subsection{SCOPE}

The term paper will look to describe the current situation in Pakistan with respect to the world scenario, and focus on the fact that a country needs to be marketed as a Brand in order to be successfully integrated as a positive part of the global fraternity. This will also be a vital cog in combating the incorrect perception of the world with respect to the country. The term paper will look at examples and case studies, and come up with conclusions and recommendations as a possible way forward. It will look to establish the importance of positive Branding for the future of the country in terms of foreigner-driven business and foreign perceptions.

\subsection{RATIONALE}

In recent years, Pakistan has grown and changed both internally and externally in terms of policy and perception. Due to acts of terrorism, the world's view of the country has become somewhat tainted. This is contrary to the 'Enlightened Moderation' that President Musharaf sees as Pakistan's future, and is also contrary to 
the huge wealth of talent that the country has in terms of professionals, the arts and tourism. Various MNCs are looking now to utilize this change in the Pakistani mindset by growing and establishing themselves further. This creates the perfect rationale for Branding the country, as this will look to dispel the negativity that surrounds the country internationally, and secondly will allow a greater degree of international business to be brought to the Pakistani industries.

The following comments by Dr. Ishrat Hussain, the ex-governor of the State Bank of Pakistan sum up the problem and the rationale behind Branding Pakistan brilliantly:

"At the moment, there is no brand called 'Pakistan'. What we do have are disjointed, largely negative, fragments of our country's attributes, which form the basis for the world's judgment...these negative images are-unfortunately-ingrained in our own minds as well, hence making our task all that much more difficult. Recent geopolitical and terrorist events have rendered this image all the more vulnerable. But in conducting a SWOT analysis, we should take this geo-political baggage as a given and work around it, rather than continue to wade in areas of controversy. Successful marketing is a function of how well the strengths are used and built on. It is important for us to be aware of our weaknesses and the threats, but even more important to channel our strengths towards seizing the opportunities." (AOPP 2006)

\section{RESEARCH METHODOLOGY}

\subsection{METHODOLOGY}

This will be a qualitative research, and will utilize articles, case studies and secondary research on the subject. The research will also include interviews with key persons who understand the current picture and the possible solutions.

The interview conducted for the purpose of this research was with Ms. Rabia Garib, member of the content development team at National IT Promotion and Development Unit (NIDU).

This paper will build upon the model she presented, and will also utilize the generic Branding model that is presented in Scott M. Davis' Brand Asset Management.

\subsection{SOURCES OF INFORMATION:}

- Brand Asset Management by Scott M. Davis

- Various Websites, articles and Case Studies

- Interview with Ms. Rabia Garib. 


\section{DATA ANALYSIS AND FINDINGS}

\subsection{WHAT IS BRANDING?}

Branding is not simply about naming a product, or creating a logo for it (Davis, S.M. (2002)). On the other hand, it relates to creating a distinct unique identity for a product or a service, so as to allow the consumers to identify the Brand with respect to its personality and the feelings that it brings out within the minds of the consumers.

According to Al Ries, a Brand creates a difference in the minds of the consumer in terms of image. It can be a set of promises, and it can imply trust and consistency, simultaneously answering expectations. Put in other words, the Brand becomes a single idea in the minds of the consumer with respect to the identity of the product.

Hence, a Brand becomes a physical/emotional trigger which creates a relationship between the consumers and the product.

Branding becomes important because stronger Brands can

- Increase Brand loyalty,

- Increase business,

- Improve the Brand Owners perception of themselves,

- Improve the Brand's perception in the mind of the consumer,

- Allow the embodiment of a clear, valued and sustainable point of differentiation relative to the competition,

- Allow for a clear positioning of the Brand, which would embody the Brand Essence.

(Davis, S.M. (2002))

The only potential disadvantage of Branding a product/service is the cost of the inputs that will go into the Branding activities.

Let's take a look at a model which looks at how a Brand can be broken down into different facets. This model is called the Brand Picture (Davis, S.M. (2002)), and takes a look at the position of the Brand in one instance of its existence.

Buyer Purchase Decision

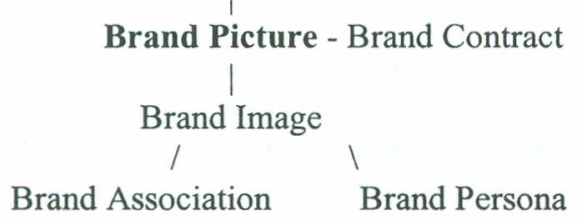


As we can see, the buyer purchase decision revolves around the Brand Picture, which is made of the Brand Contract, the Brand Association and the Brand Persona.

The Brand Contract is defined as a set of promises that the Brand makes with the consumer, which are communicated via a number of media. The Brand Persona deals with the personality of the Brand; i.e. if the Brand were human, what human attributes it would have. The Brand Associations are the feelings, entities or people that are associated or linked with the Brand. These are the things that come to mind instantly once the Brand is mentioned.

Brand Associations work on a three level pyramid, which is shown below. (Davis, S.M. (2002)). At the bottom level, the Brand relies on its Features and Attributes, while at the middle, the consumer remembers it because of its Benefits. It is at the top level where the core benefits of Branding are obtained, and it is here where the consumer feels when the Brand comes to mind; its here when the consumer believes in the Brand, and where the Brand becomes a lifestyle, rather than simply a product. Think of Nike and you'll be at the top of the pyramid.

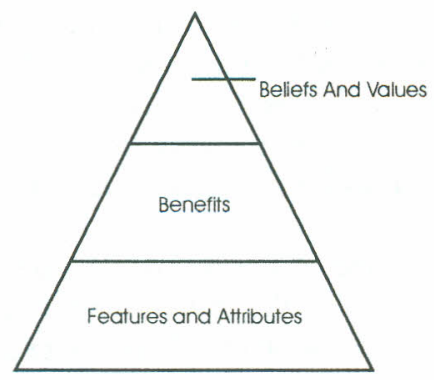

\subsection{BRANDING STATES}

So far we have looked at Branding as a means of selling a product or a service. Now we will take a different direction and utilize the said model to use Branding as a means of packaging a country or a state.

Before we embark on redefining the concepts outlined above, it is important to think of a country as a product. A country involves a number of opportunities and services, such as tourism or software production, and these form as the underlining attributes of the country packaged as a product. Once seen as a product, the country can be marketed as a Brand, and positioned or re-imaged in a way that is suitable.

Randall Frost, in an article on Branding Countries on brandchannel.com, agrees and quotes the example of $\mathrm{GE}$ being the umbrella brand for its many subsidiaries. $\mathrm{He}$ sees a similar direction with countries, where a country can act as the Umbrella 
Brand for its subsidiary industries or products, such as tourism or factory sites (Frost, R. 19 April 2004). A national branding effort is, therefore, exigent as it is inextricably linked to the products, corporate brands and services of the country. (Sya, L.S. 4 Oct 2004)

With respect to the Branding of States, this paper redefines the key concepts which were put forward before.

When we talk about consumer buying a Brand, with respect to countries it becomes redefined to consumer using the Brand or its constituents. Suppose if a person were to go to Goa in India, simply because it has been marketed as a tourist destination within the Brand India, then that would constitute Brand Usage.

Brand Contract with respect to countries would refer to the promises that the Umbrella Brand and its constituents make to the potential users or consumers. Brand Malaysia, for example, promises exotic locales and the true embodiment of Asia.

Brand Persona for countries takes the shape of the Country's representation as a human. This can take the shape of the typical citizen of the country's personality type, the personality type that stems from the heritage of the country, or a personality type that is defined by the marketers of the country's Brand. For example, the persona for India is a female; who is both confident with its modernity and at the same time able to identify with her core heritage and cultural values.

Brand Associations take the shape of the feelings, values; or benefits and attributes that the Brand Country brings out in the user's mind. For example, India brings out images of mysticism and jungles; of snake charmers and elephants; and of an able software industry, to name a few.

It is also important at this juncture to visit to other important concepts which are vital with respect to Branding. These are Brand Ownership and Brand Controllers.

Brand Owners are defined to be all the members within the company that owns the Brand (Davis, S.M. (2002)), or all members within the Umbrella Brand. Hence, for a Brand Country, the owners of the Brand are all the citizens of the country, including the expatriates and those who currently reside elsewhere.

Brand Controllers are defined as those who control the sales, policies, positioning, branding and marketing of the Brand (Davis, S.M. (2002)). In case of countries, it would be logical to assume that the Government, in partnership with the marketing agencies would be considered the Brand Controllers. It would be important to have a degree of public opinion as well, with respect to policies and direction (Frost, R. 19 April 2004). 
When marketing expertise is lacking within government, however, it may be possible for countries to enlist the help of outside professionals. Costa Rica beat out Brazil, Chile and Mexico to become the site of Intel's first Latin American plant in 1996 by drawing on the resources of its own investment promotion agency and the Irish Development Agency. Likewise, Columbia is today the major exporter of coffee to the US, largely because the National Federation of Coffee Growers of Colombia built a successful marketing campaign for Café de Colombia. (Frost, R. 19 April 2004)

There a number of challenges and questions that need to be answered with respect to Branding Countries:

- Moving around the weaknesses and being truthful,

- How effectively has the brand been designed and who is to be its messenger? (Frost, R. 19 April 2004)

- What quality should these messengers have? (Frost, R. 19 April 2004)

- Positioning the Brand with respect to its strengths and opportunities,

- Leveraging the power of its people and the Brand Owners,

- What is the relationship of the brand to other place brands in the area, country, or continent? (Frost, R. 19 April 2004)

- Cost vs. Benefits and analysis of effectiveness criteria,

- How will the brand attributes be perpetuated through time and from generation to generation? (Frost, R. 19 April 2004)

- Does the Brand fit in with its Environment, with its heritage, and with the perception of its Owners? (Frost, R. 19 April 2004)

There are a number of advantages, and these include:

- Improved image externally of the country,

- Positive aura over the country's products and services, influencing tourism, industry and purchase decisions,

- Improved image internally of the Brand Owners towards their brand, successful branding can result in improved morale, sense of purpose, higher standard of living and national pride. (Frost, R. 19 April 2004).

- Improved international business within the country resulting in improved foreign exchange and economy,

- Increasing the number of jobs available within the country,

- Improved infrastructure, to ensure that the Brand Promise is consistent and delivered.

\subsection{CASE STUDIES}

There are a number of international example which can be used as case studies and example for the exercise of Branding Countries. These include David Ogilvy's creation of Puerto Rico's Brand Essence of a "Tropical Paradise", Dubai's "Fly 
Dubai, Buy Dubai" and "Surprisingly Singapore". (Murari, G. S. 24 Feb 2005) Matthew Healey observes that Spain has made tremendous strides in branding itself as a modern and developed country, while Denmark has successfully branded all of its government ministries and departments. Croatia for its part, he notes, has been working to reform its image in sports and tourism, and Poland has begun asserting itself in foreign policy (Frost, R. 19 April 2004). The Chinese brand Haier, originally state-owned and producing low-quality electrical goods for the domestic market, is a great example of reversing the poor image of Chinese goods. Haier's business philosophy and policy rested on three planks: Brand First, Innovation and World Class Quality. It now commands an impressive market share in the US with the manufacture of high quality white goods. As a Chinese brand, Haier helps elevate the perception of Chinese goods. (Sya, L.S. 4 Oct 2004). Another popular example of Country Brand building is Malaysia's "Truly Asia" campaign.

For the purpose of this paper and its study, we will break down Brand India to its core and use it as an example of how Pakistan can be made into a Brand.

\subsubsection{Brand India}

The sometimes spontaneous and sometimes constructed Brand India (Murari, G. S. 24 Feb 2005) has recently become very visible on the various media, through its "Incredible India" campaign. It can be argued that the said campaign caters the tourism industry (Murari, G. S. 24 Feb 2005), while as it was stated before, tourism can take the shape of a single constituent within the Promise of Brand India.

Unilever India's MS Banga, defines a Brand as "the starting point which defines the philosophy, the ethos and the culture of the brand, which must then be reflected and manifested in each and every facet of the brand." (Murari, G. S. 24 Feb 2005) For India, the single underlying brand idea, or Brand Essence being marketed is "Incredible India". This embodies all of the strengths of India, and the opportunities it can provide.

But what is Brand India made of? Economist Jairam Ramesh breaks down Brand India into five components:

1 - It is a Multi-Layered Brand: This refers to the inherent diversity in terms of religion, language, caste and creed within India. (Ramesh, J. 24 Feb 2005)This ideology has been encompassed within the Essence and positioning of Brand India. 2 - It is a constantly Evolving Brand: This refers to the changes within the Brand's personality. From an importer of Wheat, it has now become the World's IT Capital. (Ramesh, J. 24 Feb 2005) This is also quite present within the Persona of the Brand, and is regarded as one of the opportunities that the West has with respect to India. 
3 - It is an Aggregate Brand: This idea is similar to the earlier discussion of an Umbrella Brand and its constituents. Ramesh breaks down Brand India into various other Brands, such as Brand Bollywood ("We make movies"), Brand Chennai, Brand Kolkatta and Brand Bangalore ("Asian Silicon Valley") to name a few. (Ramesh, J. 24 Feb 2005)These are all sub-brands which cater to and compliment the success of greater Brand India.

4 - It is a Brand in Transition: This refers to the changing mindsets and cultural transitions that are undergoing within India. It also refers to the changes in Policies and Politics within India. It is undergoing an Economic Shift. (Ramesh, J. 24 Feb 2005) This aspect of Brand India can be viewed as both a strength or a weakness by external stakeholders, but it is important to note that in the implantation of their Branding Strategy, they have not steered away from the reality.

5 - It is a Brand with its own unique Psychology: This refers to the localized manner of thinking that the consumers and stakeholders exhibit with respect to Brands and economy. This can again be looked at as a Strength or a Weakness.

It is heartening to note that for Brand Pakistan, most of the above fall into place, and where India has been successful, so can Pakistan. But certain areas need to be developed first. Still, India is a good example to take reference from:

\subsection{BRAND PAKISTAN: THE CURRENT REALITY}

Talk about Pakistan to most people from the West, and the impression you would get is that Pakistan is a country where woman are oppressed, terrorists breed, Islam has become extremist and no concept of modernity exists. The irony of this picture is that it is not entirely true (Alam, S. A 12 March 2005).

Similar to most developing countries, Pakistan does face its share of problems, and these range from health and poverty to terrorism and education. But largely, the country is moving towards Enlightened Moderation, and has a number of opportunities which the West and Europe can utilize. Cities like Karachi and Lahore are modern cities at par with other world cities, and the citizens in no way are different from their peers across the world.

At the same time, countries around Pakistan, such as India, have invested a great amount of time and money into marketing and branding activities to improve the world perception of their existence. Within this environment, it would largely be suicidal for Pakistan not to move in a positive direction with respect to Marketing and Branding itself. 
Before we come to a SWOT analysis of Pakistan that will illustrate the potential of the country, let's take a look at how Branding Pakistan can help the country:

1. A positive Brand Pakistan will improve the world perception of Pakistani Muslims as modern empowered Muslims in particular, and Islam and Muslims and general. The erroneous use of 'Terrorism' and 'Islam' as one word should be reduced worldwide, and a positive branding campaign for one of the primary Islamic countries in the world will certainly help in this respect.

2. A positive Brand Pakistan will improve the degree of patriotism, pride and drive of Pakistanis within the country and abroad. They will feel they belong and will be proud of their heritage and background as Pakistanis and/or as Muslims. This will lead to improved situations of integrity, self worth and self-actualization for the Pakistani populace and as a result, for Pakistan as a whole (Casey, E. 12 June 2006).

3. A positive Brand Pakistan will help Pakistan in terms of the political leverage it holds in the Global community as a nation, and also for its individuals. This will not only help Pakistan get an improved outlook from the world, but the campaign will train the local media in tasks of positive propaganda and positive imaging. This will go a long way in combating negative propaganda from external sources.

4. A positive Brand Pakistan will help the tourism industry of the country, and is liable to turn potential tourism hot spots such as Karachi, Lahore and the North into a great source of revenue.

5. The positive Branding will also help in incoming foreign business, and will encourage foreign investors and companies to invest in the country and to grow by utilizing the opportunities that are unique to Brand Pakistan.

6. A direct effect of Brand Contract maintenance will be the improvements that the Pakistan infrastructure will receive, in terms of health, transport, jobs, security, and its likes.

7. A positive Brand will allow Pakistanis to be one with the social community more proactively, and this will allow for exchange of ideas and processes, which will help both Pakistan and the world community.

8. A positive Brand will reduce the brain drain that takes place from Pakistan, and would allow the country to utilize its best minds for its own benefits.

At this juncture, a SWOT analysis would be appropriate to get a good view of what is the task that is facing the Brand Controllers and what are the areas that need to be marketed and areas that need to be improved. (AOPP 2006) 


\section{STRENGTHS}

- Uniqueness and internal regional richness and diversity in Culture, Music, Poetry, Writing, Cuisine, Arts \& Crafts and Fashion.

- Increased global representation in Visual Arts, Fashion, Music and the Creative Arts.

- Cultural Diversity.

- Rich Heritage and History.

- Rise of women in certain roles, such as in politics, media, arts and academia. Gradual empowerment of women in certain areas.

- Strong personalities in both current environment and in history of country.

- A large young population.

- Large percentage of technically very apt and professional work force.

- Better potential of communication in English by the work force than say Indians.

- Hard working and hungry for success work force.

- Entrepreneurial capability.

- Good amount of Manufacturing capabilities and potential within country.

- A number of industries that have the capacity to be world beaters, such as Textiles, Tourism, IT and Sporting Goods.

- Exceptional Agriculture capabilities and crops such as rice.

- Beautiful physical landscape.

- Architectural and historically rich tourist attractions.

- Strategic geo-politcal position.

- Strong Value Systems.

\section{WEAKNESSES}

- Lack of Democracy.

- Law and Order.

- Infrastructure lacking in major cities.

- Transportation System lacking.

- Health and Sanitation.

- Education.

- Lack of strong and true institutions.

- Increased loss of Value System.

- Economic Dichotomy

- Lack of Identity and pride as a Pakistani.

- Ethnicity

- Feudalism 
- Violence on down trodden women and minorities.

- Corruption.

- Extremism and Taliban seeping in from NWFP.

- Lack of Industrial, Tourism and Economic infrastructure and planning.

- Cynicism in population.

- Over population.

- Religions Extremism.

- Lack of Positive Media Coverage

\section{OPPORTUNITIES}

- Technology and IT

- Outsourcing

- Telecom industry

- Tourism and Other industries.

- Professional, technically able and English speaking work force.

- Bridge between Muslim World and the West.

- Bridge into CAR.

- Port of Gwadar.

- Arts and the Media.

\section{THREATS}

- Increased Indianization and Americanization of cultural values.

- War on Terror and Extremism

- Taliban and Al Quaida

- Negative Media propaganda

- Aggressive neighbors

- Drugs and Gun culture

- Fascism

With the above in mind, it becomes a fairly diverse picture which takes a look at the scope of Pakistan with respect to its Branding initiative and global opportunities.

As it stands, there are no real initiatives to officially look towards Branding Pakistan. There are individual initiatives, such as the Association of Pakistani Professionals that kicked off a series of seminars, termed as "Brand Pakistan - Developing and Establishing a Positive Brand” in June 2006. (The Saturday Post, November 2006) Other initiatives include personal Blogs and websites aiming to fight of negative press worldwide, and Rabia Garib's proposal to NIDU which advocated the formation of a Pakistan Portal (Personal Communication, Garib, R. 2006). Rabia Garib is the editor-in-chief of Rasala Publications, and a member of NIDU's Content Development team, along with being a Media Advisor to the IT Ministry. 
The only potential stumbling block that the government can face is that of cost, but given the long term benefits that were outlined above, the cost factor continues to lose its importance.

\subsection{BRAND PAKISTAN: THE WAY FORWARD}

Having taken a look at the ground reality, the way forward is two-fold: first of all the government or the relevant stakeholders will have to decide to go ahead with the Branding of the Country, and the second and more important factor will be to develop the infrastructure and to work on the weaknesses of the country in order to be able to cater to the Brand Contract that Pakistan will create for itself.

An analogy would be apt at this juncture, just as bringing the Olympics to country involves both improving the infrastructure and facilities, along with bidding and wanting to have the Olympics; a Branding initiative will have to work in parallel with the improvement of facilities and infrastructure of the country.

Let's take a look at some of the areas that need to be improved:

1. Creating Systems, Processes and improving Institutions (Varughese, S. 27 June 2005). This refers to various systems and processes in place for various tasks, such as the granting of licenses for foreign businesses and their likes; along with ensuring that the important institutions such as the Courts and the Police have quality and stakeholder oriented Systems and Processes, which will ease problems for stakeholders.

2. Human Resource Management will need to be improved. This refers to the integration of the graduates of the country and the improving of the Education systems so that the future graduates can have a greater flexibility of skills. This also means that policies will have to be put into place that will look to create satisfaction for the HR of the country, so that pride can increase and brain drain can decrease. Most importantly, nepotism will have to be put to bed and a merit based HR system will have to be implemented all over the country.

3. Improving the Educational Backbone (Varughese, S. 27 June 2005). This involves improving the literacy rate, improving the primary and secondary quality of education, improving female education, putting in place affordable educational institutions, and ensuring that the higher level universities and educational institutes are at par with the world in terms of syllabus and curriculum. Teacher incentives will have to increase, and respect must be put into place for the teaching profession so that we can retain our best teachers and produce good teachers for the future. 
4. Core infrastructure must be improved, and this pertains to areas such as Industries, Transport, Health and Sanitation, and Law and Order.

Having taken a look at the basic level of improvements that need to start being implemented, it would be the appropriate time to have a look at a potential way forward for the stakeholders to go about Branding Pakistan.

1. First of all the government must set about a five year plan with two core objectives in mind: first being the improvement of the areas mentioned above, and secondly, setting the tone for the starting of the Branding Initiative.

2. The relevant stakeholders must decide who is to be the Brand Controllers. It is obvious that the Brand Owners are the citizens, and it would be advisable that a relevant government task force or committee be set up, which would work hand in hand with local marketing and Brand management companies to set about the Branding Initiative.

3. The said task force should come together along with the Branding Professionals, and a relevant cross-section of individuals from the Pakistan populace, (such as the AOPP and other independent bodies that have looked to improve Pakistan's image) including relevant professionals, such as expatriates, journalists, industrialists, entrepreneurs, students and so on, to come up with the Brand Essence, Brand Associations, Brand Persona and Brand Contract of the country. When this paper mentions the presence of the assortment of relevant individuals, it does not intend implying that a huge task force should debate over what the Brand Picture should contain; rather we propose a very lean but representative group that can hold discussions with relevant bodies and individuals to come up with the content of the Brand Picture.

4. The government should set about to improve the infrastructure and the 4 key areas listed earlier in parallel to Brand Activation process, in order to ensure that the Brand Contract is achievable and true. It is suggested that the government concentrates on tourism development, by identifying key tourism areas, and developing the said areas to increase foreign traffic in these areas. It would also be advisable to have professionals working in these development task forces so that the Tourism Industry will have a professional look about it.

5. The Brand Controllers should initiate a process of internal marketing, as soon as the Brand Picture content is finalized. It is vital to initiate patriotism and pride for the country at the individual level, so that the citizens of the 
country can feel empowered and feel that they belong. This would help in assuaging the problem of the lack of identity, Americanization and Indianization that the country is grappling with. Once the individuals within the country know what Brand Pakistan stands for and promises, each of them can work towards the delivery of that promise. Brand Pakistan, after all, can only be as strong as its constituent Brands, and the individuals who make up the various sub-Brands. A possible slogan for the internal marketing campaign could be Live Pakistan, Breath Pakistan; Be Pakistani.

6. The core competencies that the country has should be leveraged to initiate the campaign internationally. Expatriates, the Pakistan visual Media, Pakistan print media and technology representatives and professionals should be positioned at the fore-front of the campaign. The positioning of Brand Pakistan should be clear, and identifiable, and easily communicable. A slogan that encompasses the Brand Essence would greatly help the cause. A potential example could be The Greenest Pakistan. Leveraging the power of a Pakistani recognizable in the world community would also be greatly helpful, and for this purpose, individuals such as Imran Khan and Shaukat Aziz who have achieved much internationally, along with the many individuals from our youth who have achieved international fame in various academic, arts and political fields, should be put forward as Brand Ambassadors or spokespersons for the Brand Pakistan. The campaign could actually be multi-fold, showcasing the various facets of Pakistan such as Sports, Fashion, Photography, Writing, etc. Each facet could have a representative.

7. A web portal should be implemented, based on the model presented by Rabia Garib (Personal Communication, Garib, R. 2006), which would present Pakistan to the world community. This Paper proposes building upon the model so that the Portal would encompass all major facets of the Pakistani society, such as Arts, industries, IT, Telecom, Media, Medicine, Fashion and their likes. Each facet would be easily accessible by the world community through the internet, and would present a Blog like structure, whereby the world can see dynamic examples of what Pakistanis are capable of doing and what they have done. Writers, Expatriates, professionals and intellectuals from the country can use this portal to write and create awareness internationally about the various facets of Pakistan that they represent. The figure below is a potential model, presented here with permission and with thanks to Ms. Rabia Garib, whose intellectual property it is. 


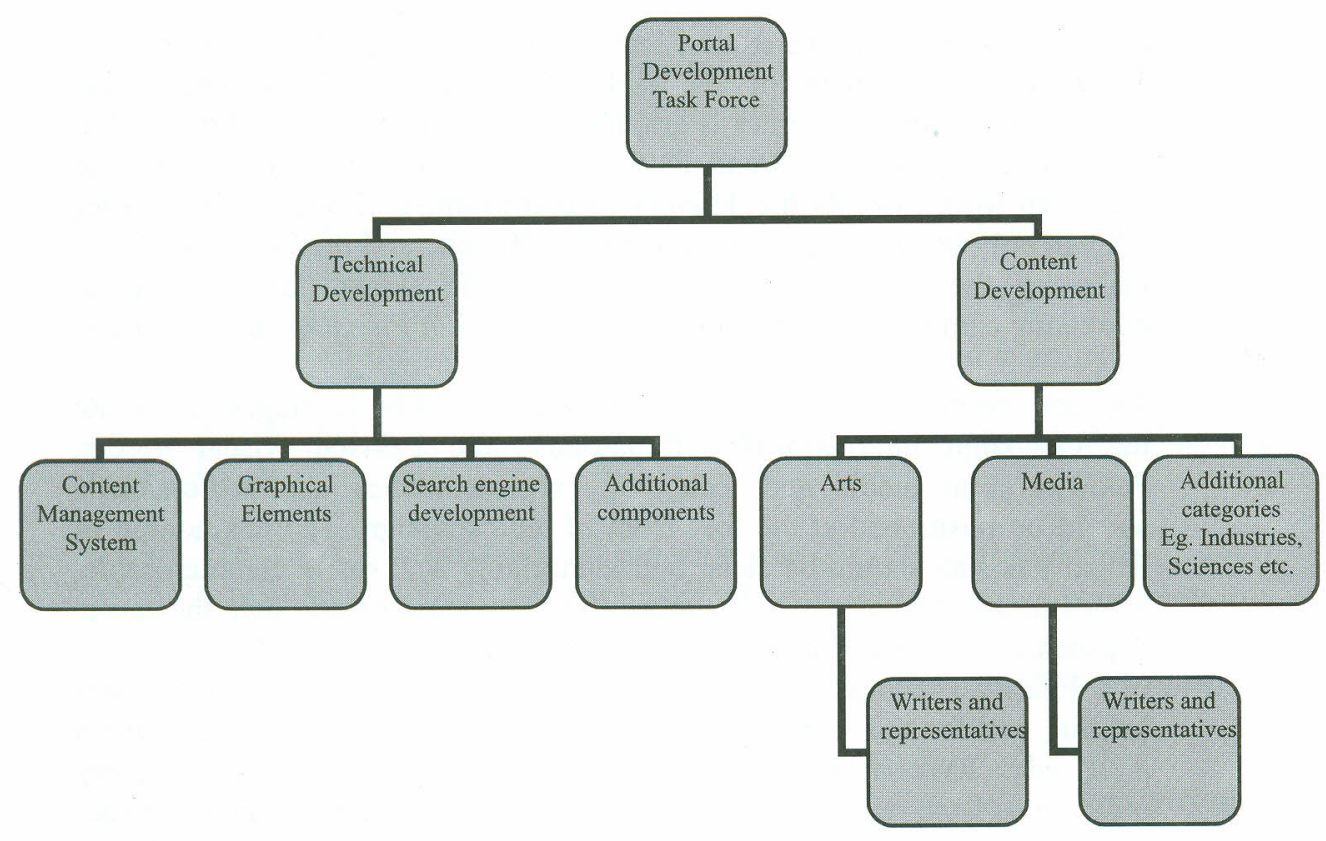

\section{CONCLUSION}

Having taken a look at potential examples to follow, and having looked at the benefits that Branding can bring about; it would be a primary recommendation from this paper for the relevant stakeholders to initiate the process of infrastructure development and subsequently the Branding Pakistan campaign.

This paper recommends the above because of the following primary reasons:

1. Brand India and various other countries have used Branding successfully, and it would be about time that we go about to develop the Brand Pakistan so that we do not fall behind and are able to be competitive in the world environment.

2. There is a huge need to improve the country's image and infrastructure, and the Branding initiative would go about towards achieving this aim.

3. There is a massive need for Pakistan to be able to fight the negative propaganda perpetuated against it, and the Branding initiative would be a great step in that direction. 
4. Finally, Branding Pakistan would be a great step towards the development of the country's Natural, Physical, Economic and Intellectual Assets; and for instilling pride in a country struggling to recover its identity.

\section{REFERENCES}

\section{PRIMARY SOURCES}

Davis, S.M. (2002). Brand Asset Management, Josey-Bass, p. 6-20, 35-60.

\section{SECONDARY SOURCES:}

Alam, S. A 12 March 2005, Branding Pakistan, The Nation http://www.aopp.org/branding.htm

Casey, E. 12 June 2006, Rebranding Pakistan, The South Asian

Htt://www.thesouthasian.org/archives/2006/rebranding_Pakistan.html

The Saturday Post, November 2006, Developing and Establishing a Positive Brand, The Saturday Post http://www.thesaturdaypost.com/spotlight_43_brandpakistan.html

Ramesh, J. 24 Feb 2005, Defining Brand India, The Hindu Business Line http://www.blonnet.com/catalyst/2006/0224/stories/2005022400020300.htm

Murari, G. S. 24 Feb 2005, Can India be a Brand, The Hindu Business Line http:/www thehindubusinessline.com/catalyst/2005/02/24/stories/2005022400260200.htm

Varughese, S. 27 June 2005, Dubai Country Brand, Brandchannel.com http://brandchannel.com/features_profile.asp?pr_id=238

Sya, L.S. 4 Oct 2004, Branding Malaysia, Brandchannel.com http://brandchannel.com/features_profile.asp?pr_id=200

Frost, R. 19 April 2004, Promoting Place or a Region, Brandchannel.com http://brandchannel.com/features_effect.asp?pf_id=206

AOPP 2006, Brand Pakistan, http://www.aopp.org/brandpakistan.htm

Personal Communication, Garib, R. 2006, Member, NIDU

Capacity for the nobler feelings is in most nature a very tender plant, easily killed, not only by hostile influences, but by mere want of sustenance; and in the majority of young persons it speedily dies away if the occupations to which their position in life has devoted them, and the society into which it has thrown them, are not favourable to keeping that higher capacity in exercise.

John Stuart Mill, Utilitarianism (1863) 